\title{
The densities of fiber follicles in the Karakaş, Norduz, and Zom sheep and a comparative analysis
}

\author{
Selçuk S. Tuncer ${ }^{a *}$, Sema Uslü ${ }^{\mathrm{b}}$, Abuzer Taş ${ }^{\mathrm{c}}$, Halit D. Şireli ${ }^{\mathrm{d}}$
}

\begin{abstract}
This study aimed to determine the densities of fiber follicles in the skin of the Karakaş, Norduz, and Zom sheep breeds and to carry out a comparative analysis between them. The study included a total of 36 animals aged 1-2 years and 3-4 years. Skin samples were obtained through biopsies taken from the right sides of the animals to determine the densities and ratios of the fleece follicles. Examination of these samples revealed that the primary follicle densities of the three sheep breeds (Karakaș, Norduz and Zom) were $3.11 \pm 0.42,3.14 \pm 0.49$ and $3.34 \pm 0.59$, while the secondary follicle densities were $8.42 \pm 1.48,8.51 \pm 1.54$ and $6.36 \pm 1.44$. The secondary to primary $(\mathrm{S} / \mathrm{P})$ follicle ratios of the sheep were $2.71 \pm 0.70,2.79 \pm 0.69$ and $1.85 \pm 0.36$, respectively. The primary follicle densities of the Karakaş, Norduz and Zom sheep were statistically similar for both age groups. The density of secondary follicles and S/P ratio decreased with age in both age groups. The similarity of the S/P ratios to those from other local sheep breeds suggest that Karakaș, Norduz, Zom sheep can be included in the sheep group that has coarse fleece.
\end{abstract}

Key words: fleece follicle, Karakaş, Norduz, Zom.

\section{INTRODUCTION}

The origins of modern domestic sheep (Ovis aries) are not well known (Hiendleder et al 1998). It is generally believed that sheep domestication occurred about 10000 years ago (Krebs and Krebs 2003). Groves and Leslie (2011) suggest that the Anatolian Sheep or Asiatic Mouflon (Ovis gmelini) is likely to be the ancestor of modern sheep breeds.

Turkey has about 31,507,934 sheep (TUIK 2016), and is one of the most important sheep-breeding countries in the world. There are a variety of sheep breeds that have adapted to its different climate conditions and have different productivity properties (Özcan 1990). Some of the breeds or types of sheep are bred mainly in the Eastern and Southeastern Anatolia regions of Turkey. In addition to the well-identified breeds found in this region, there are also some yet unidentified sheep breeds, such as the Norduz, Karakaş (Kaymakçı 2006) and Zom (Koncagül et al 2012) sheep, which are likely to be White Karaman varieties. However, few studies have been conducted on the fiber follicles of the Norduz and Karakaş sheep (Tuncer and Cengiz 2009), and there are no studies on those of the Zom sheep. Norduz sheep are bred in the Norduz Plateau in the Gürpınar County of Turkey's Van Province, Karakaş sheep are bred in the vicinities of

Accepted: 28.09.2017.

aDepartment of Crop and Animal Production, Ozalp Vocational School, University of Van Yuzuncu Yil, Van, Turkey.

${ }^{b}$ Department of Histology, Faculty of Veterinary Medicine, University of Cumhuriyet, Sivas, Turkey.

'Department of Surgery, Faculty of Veterinary Medicine, University of Van Yuzuncu Yil, Van, Turkey.

dDepartment of Animal Science, Faculty of Agriculture, University of Dicle, Diyarbakir, Turkey.

*Corresponding author: S Tuncer; selcukseckintuncer@gmail.com
Van and Bitlis (Bingöl et al 2007), and Zom sheep are bred in the Karacadağ region, extending over a dormant volcano along the Diyarbakır-Mardin border (Koncagül et al 2012, Tuncer et al 2016).

Primary follicles are fully formed in the mother's wombs during the first trimester of gestation (Lyne 1961) and are, therefore, significantly affected by genetic conditions (Corbett 1979). Changes in the density of the primary follicles after birth can be associated with the changes that occur in the skin surface area as a result of live weight gain (Lyne 1961). The fibers originating from the primary follicles provide mechanical protection and are usually medullated and thicker than $35 \mu$ (AnsariRenani et al 2011).

Secondary follicles are reported to be formed after the $85^{\text {th }}$ day of gestation (Carter 1955, Hutchison and Mellor 1983, Tuncer and Cengiz 2009) and continue to develop after birth (Hatcher and Johnson 2004, Tuncer and Cengiz 2009). These follicles provide thermal protection, are found in the skin in greater densities than those of the primary follicles, and usually produce non-medullated fine fibers $(<35 \mu)$ (Ansari-Renani et al 2011).

Secondary to primary $(\mathrm{S} / \mathrm{P})$ follicle ratios vary among the different sheep breeds (Chapman and Ward 1979) and are determined by the fleece cover-based classification. Ryder and Stephenson identified the follicles that form the properties of the fibers for coarse fibers, heterotypic fibers, fine fibers, and kemp fibers and showed that the differences in the $\mathrm{S} / \mathrm{P}$ ratios were determined by their classifications (Hatcher 2002).

The aim of the study was to examine the characteristics of the Karakaş, Norduz, and Zom sheep, considered as White Karaman varieties, by investigating the primary follicles which are considerably affected by the genetic structure of the sheep, and the secondary follicles which are considerably affected by the environmental conditions, and also the $\mathrm{S} / \mathrm{P}$ ratios as indicators of the fleece yield. 


\section{MATERIAL AND METHODS}

The study used Karakaş and Zom sheep bred by the local community of the Karacadağ Plateau in the Diyarbakır Province of Turkey, and Norduz sheep bred in the Livestock Establishment of the University of Van Yuzuncu Yil. A total of 36 sheep from three groups, the Norduz, Karakaş and Zom, were included in the study, with each group consisting of six sheep aged 1-2 years and 3-4 years. The final report of this research project was approved by Yuzuncu Yil University Animal Researches Local Ethic Committee, decision number 2016/11.

The fleece used included the remains on the skin after fleecing with a razor blade without damaging the epidermis (Selçuk 1974). The shaved areas, which are normally stretched, were pressured with a $0.5 \mathrm{~cm}$ diameter belt stapler to obtain a circular section. Then, using a scalpel, the normally-stretched circular skin was incised deeply enough to reach the connective tissue and obtain the circular section (Batu and Özcan 1962). The body surface under the skin of the animals was disinfected with batticon and sutured with a simple interrupted suture pattern. After the operation, the animals were given parenteral antibiotics for seven days. The circular sections were placed in $10-\mathrm{ml}$ sterile bottles that had been specifically prepared, each containing $7 \mathrm{ml}$ of Maximov solution and marked with the ear number of the corresponding animal; skin sections that had been contaminated by blood were rinsed with distilled water before being added to the bottles.

The skin samples obtained from the areas between the right rib and fossa paralumbalis of the animals were fixed in 10\% buffered Formol solution for 24-48 hours. After rinsing and performing the routine histological follow-up of the tissue, these samples were perpendicularly blocked. They were sectioned to 5-6 $\mu$ thicknesses with Microtome (Leica) and stained with Crossman's triple modification (Bancroft and Cook 1984). The primary and secondary fleece follicles were counted with an ocular micrometer at 20x magnification, and the results were converted into numbers per square millimeter of skin (Özfiliz et al 2002). The skin samples were photographed using Leica ICC50.

Descriptive statistics for the studied variables (characteristics), i.e. primary follicle, secondary follicle and $\mathrm{S} / \mathrm{P}$ were presented as mean and standard error of mean. The Kolmogorov-Sminov test was used to show normal distribution of the data. General linear mixed model was performed to determine effects of animals (random effect), age group (fixed effect) and breeds (fixed effect) (SAS 2017).

Data was analysed using the SPSS statistical software package (Winer et al 1991) to determine the correlations and statistical significance levels between the follicles of the breeds.

\section{RESULTS}

Figure 1 shows sheep skin sections examined under a microscope, where the diameters of the secondary follicles that form the thin fibers were smaller than those of the primary follicles. In addition, it is clear that primary follicles have sweat glands, contrary to secondary follicles.

The averages of fleece follicle (primary and secondary) densities, S/P ratios according to ages and breeds are shown in table 1. Estimated means of secondary follicle $(7.91 \pm 1.98)$ and $\mathrm{S} / \mathrm{P}$ ratio $(2.65 \pm 0.88)$ for $1-2$ year old sheep were higher $(+0.336$ and +0.412 , respectively) than those of the 3-4 year old sheep.

Model summary statistics for general linear mixed model are shown in table 2. The average secondary follicle densities and S/P ratios of Karakaş and Norduz sheep were higher $(2.066$ and $0.844 ; 2.182$ and 0.942 , respectively) than those from Zom sheep.

Figure 2, Figure 3 and Figure 4 show primary, secondary follicle densities and S/P ratios for age groups and breeds. It is possible to observe that primary fleece follicles per square millimeter of skin area in Zom sheep were higher than those of Karakaş and Norduz sheep but lower in the secondary and S/P ratios. Likewise, the primary follicles of the 3-4 year old group were higher than those of the 1-2 year old group, but lower in secondary follicle densities and S/P ratios.

The correlations between the follicles densities and secondary to primary $(\mathrm{S} / \mathrm{P})$ follicle ratio of the sheep are shown in table 3.

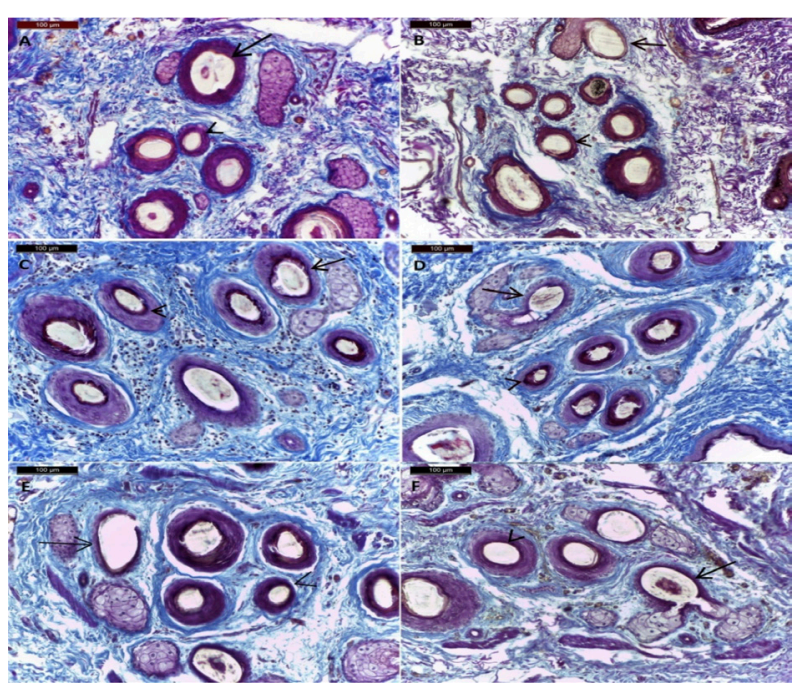

Figure 1. The follicle structure of the sheep skin sections under a microscope. A) 1-2 year old Karakaş; B) 3-4 year old Karakaş; C) 1-2-year old Norduz; D) 3-4 year old Norduz; E) 1-2-year old Zom; F) 3-4-year old Zom. Arrow markers $(\leftarrow)$ indicate primary follicles and arrowhead $(<)$ markers indicate secondary follicles, triple staining, $100 \mu$. 
Table 1. Follicle properties (mean $\pm \mathrm{SE}$ ) and comparison results.

\begin{tabular}{|c|c|c|c|c|c|}
\hline & \multicolumn{2}{|c|}{ Age } & \multicolumn{3}{|c|}{ Breed } \\
\hline & $1-2$ & $3-4$ & Karakaş & Norduz & Zom \\
\hline Number of Sheep & 18 & 18 & 12 & 12 & 12 \\
\hline Estimated mean for Primary Follicle & $3.32 \pm 0.48$ & $3.30 \pm 0,52$ & $3.11 \pm 0.42 \mathrm{a}$ & $3.14 \pm 0.49 \mathrm{a}$ & $3.34 \pm 0.59 \mathrm{a}$ \\
\hline Estimated mean for Secondary Follicle & $\# 7.91 \pm 1.98$ & $7.53 \pm 1,56$ & $8.42 \pm 1.48 \mathrm{a}$ & $8.51 \pm 1.54 \mathrm{a}$ & $6.36 \pm 1.44 b$ \\
\hline Estimated mean for $S / P$ & $\# 2.65 \pm 0.88$ & $2.24 \pm 0.46$ & $2.71 \pm 0.70 \mathrm{a}$ & $2.79 \pm 0.69 \mathrm{a}$ & $1.85 \pm 0.36 b$ \\
\hline
\end{tabular}

SE: standard error.

\#: significantly differ from 3-4 aged group $(P<0.05)$.

a, b: Different lower cases represent statistically significant differences $(P<0.05)$.

Table 2. Model summary statistics for general linear mixed models.

\begin{tabular}{lccc}
\hline Target & Primary follicle & Secondary follicle & S/P \\
\hline Probability distribution & Normal & Normal & Normal \\
Link function & Identity & Identity & Identity \\
Akaike Information criteria & 56.801 & 128.47 & 66.70 \\
Bayesian Information criteria & 58.141 & 129.81 & 68.032 \\
Coefficient for age: $1-2$ & $0.276(P=0.101)$ & $0.336(P=0.506)$ & $0.412(P=0.038)$ \\
Coefficient for Karakaş & $-0.321(P=0.118)$ & $2.066(P=0.002)$ & $0.844(P=0.001)$ \\
Coefficient for Norduz & $-0.310(P=0.130)$ & $2.182(P=0.001)$ & $0.942(P=0.001)$ \\
\hline
\end{tabular}

Table 3. The correlations between the follicle densities and secondary to primary (S/P) follicle ratios of the Karakaş, Norduz and Zom sheep breeds.

\begin{tabular}{lclccc}
\hline & $\mathrm{n}$ & & $\mathrm{P}$ density & $\mathrm{S}$ density & $\mathrm{S} / \mathrm{P}$ \\
\hline Karakaş & 12 & P density & 1 & & \\
& & S density & -0.027 & 1 & \\
& & S/P & $-0.612^{*}$ & $0.735^{* *}$ & 1 \\
Norduz & 12 & P density & 1 & & \\
& & S density & -0.068 & 1 & 1 \\
Zom & & S/P & $-0.719^{* *}$ & $0.732^{* *}$ & \\
& 12 & P density & 1 & & \\
& & S density & $0.624^{*}$ & 1 & 1 \\
\hline
\end{tabular}

$*: P<0.05$.

$* *: P<0.01$

\section{DISCUSSION}

In accordance with the literature (Lyne 1961, Corbett 1979), the similarity in the primary follicle densities of the sheep (Norduz, Karakaş and Zom) strengthens the likelihood that these sheep might be genetically similar to each other. A comparison between the average densities of primary follicles in the Karakaş, Norduz, and Zom sheep $(3.11 \pm 0.42,3.14 \pm 0.49$, and $3.34 \pm 0.59)$ (table 1 and figure 2) and those of other local sheep breeds in Turkey was made, determining that the densities found in this study were similar to those reported by Batu and Özcan (1962) in White Karaman, Dağlıç, Kıvırcık, and
Karacabey Merino sheep, by Özcan in İvesi, Karagül, Gökçeada, Sakız, and Karayaka sheep (FAO 1986), and by Tuncer and Cengiz (2009) in Norduz and Karakaş sheep. However, the densities were lower than those determined by Özfiliz (1992) in Karacabey Merino sheep, by Zik et al (1999) in Karayaka sheep, and by Kocamış and Aslan (2004) in Tuj sheep. The average primary follicle densities were similar to the Lori (Abbasi et al 2008), Afshari, Zandi, Mehrabani, and Balouchi (AnsariRenani et al 2011) breeds of Iran, which is one of the most important sheep-breeding countries in the region, but were significantly lower than those of the Omani Native breed (Mahgoub et al 2010). 

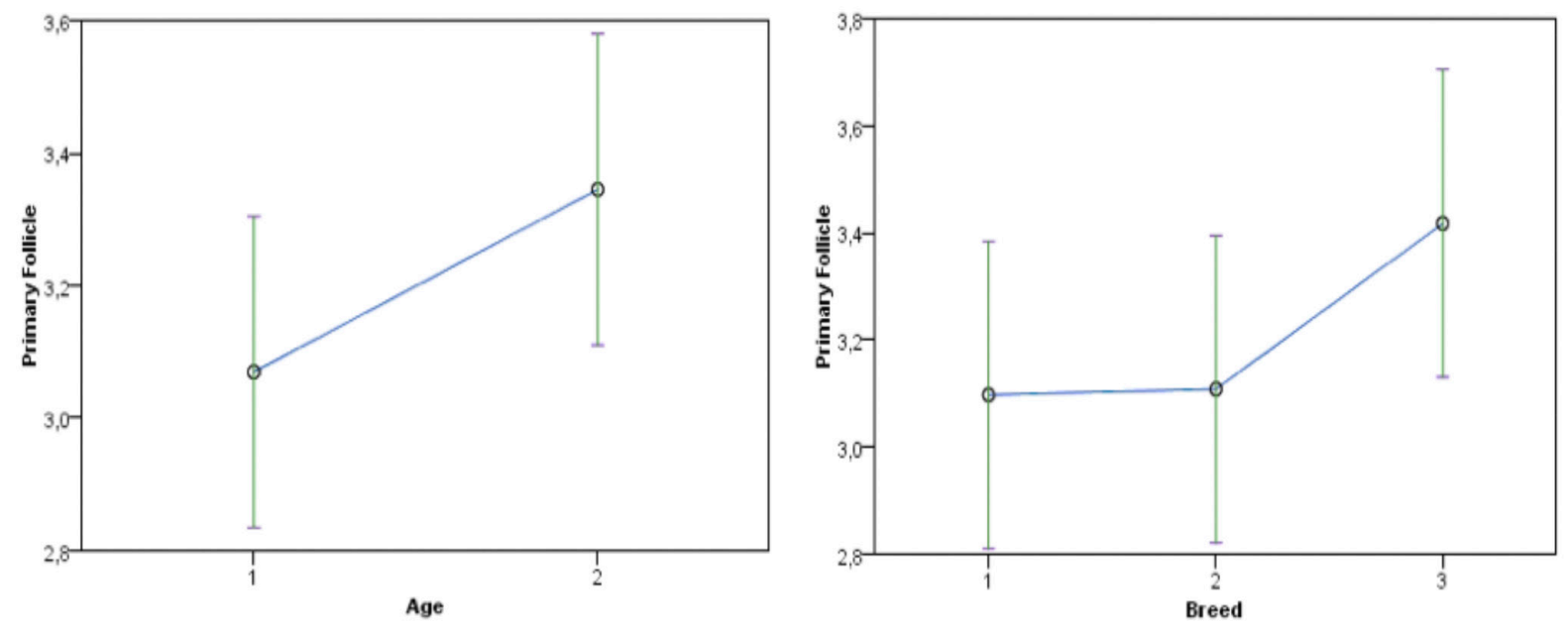

Figure 2. Estimated means of primary follicle for age groups and breeds (1: 1-2 years old; 2: 3-4 years old; Breed 1: Karakaş; 2: Norduz; 3: Zom).
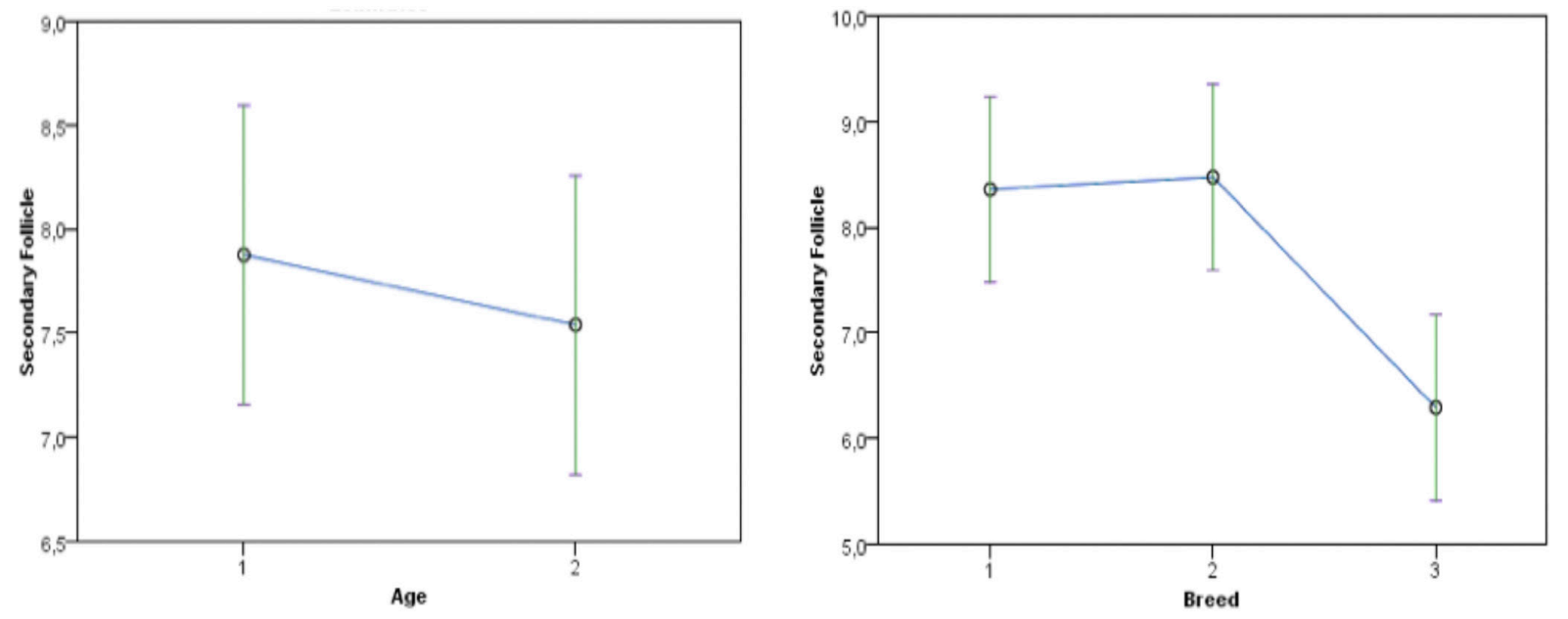

Figure 3. Estimated means of secondary follicle for age groups and breeds (1: 1-2 years old; 2: 3-4 years old; Breed 1: Karakaş; 2: Norduz; 3: Zom).
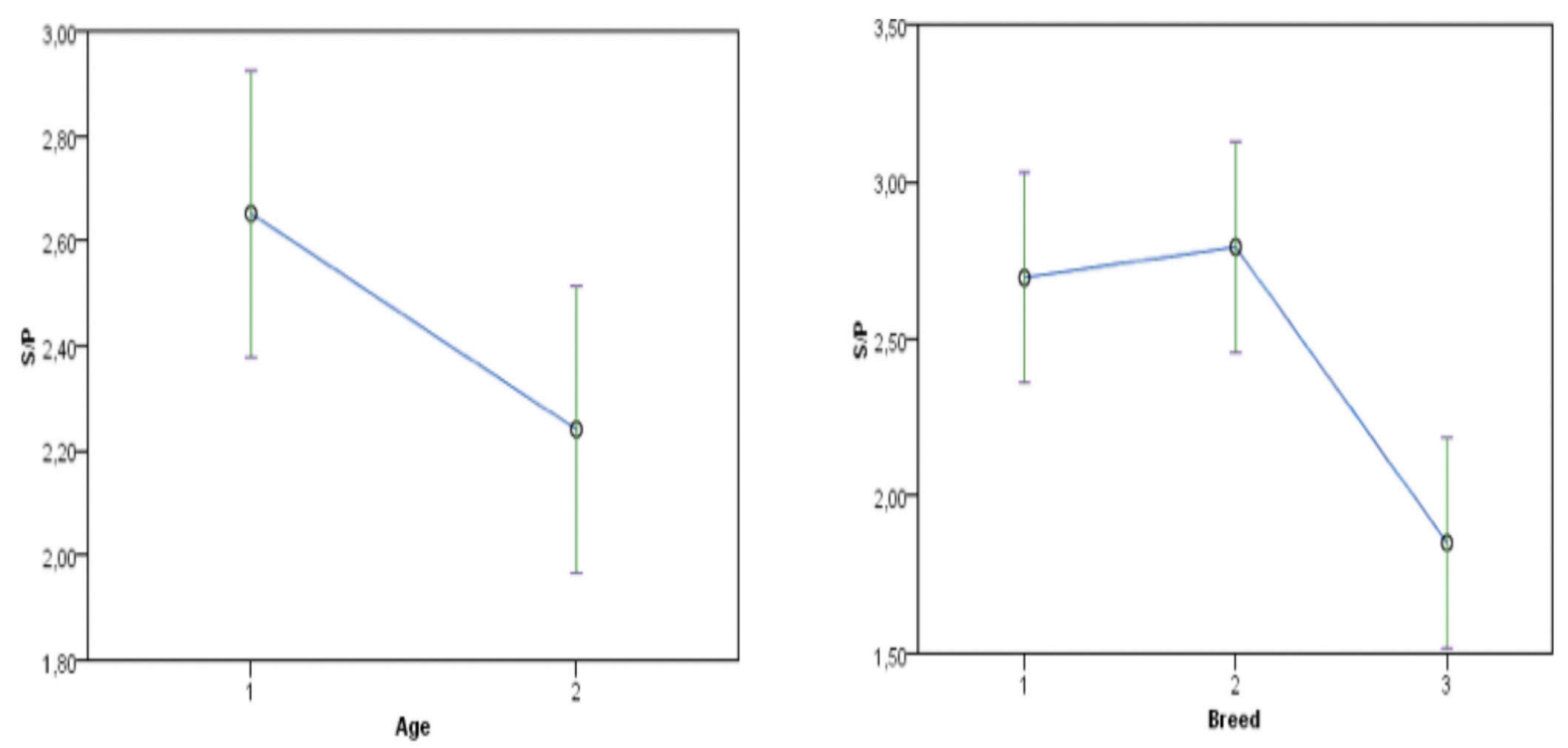

Figure 4. Estimated means of S/P ratio for age groups and breeds (1: 1-2 years old; 2: 3-4 years old; Breed 1: Karakaş; 2: Norduz; 3: Zom). 
The average secondary follicle densities of the Karakaş, Norduz, and Zom sheep $(8.42 \pm 1.48,8.51 \pm 1.54$, and $6.36 \pm$ 1.44) (table 1 and figure 3 ) were similar to those determined by Batu and Özcan (1962) in White Karaman and Kivircık sheep and by Özcan in İvesi and Karakaya sheep (FAO 1986). On the other hand, the average densities were lower than those reported by Batu and Özcan (1962) in Dağlıç and Karacabey Merino sheep and by Özcan in Karagül, Gökçeada, and Sakız sheep (FAO 1986). The values were also lower than those of the Karacabey Merino (Özfiliz 1992), Karayaka (Zik et al 1999), and Tuj (Kocamış and Aslan 2004) sheep but were higher than those reported by Tuncer and Cengiz (2009) in Norduz and Karakaş sheep. The average secondary follicle densities were similar to the Lori (Abbasi et al 2008), Afshari, and Mehrabani (Ansari-Renani et al 2011) sheep but lower than those of the Zandi, Lori, Balouchi (Ansari-Renani et al 2011), and Omani Native (Mahgoub et al 2010) breeds.

The average S/P ratios of the Karakaş, Norduz, and Zom sheep $(2.71 \pm 0.70,2.79 \pm 0.69$, and $1.85 \pm 0.36)$ (table 1 and figure 4) were lower than those of the White Karaman, Dağlıç, Anatolian Merino (Batu and Özcan 1962), Karacabey Merino (Artan 1988, Özfiliz 1992), and Karayaka ( Zik et al 1999) sheep and similar to the ratios of the K1virc1k (Batu and Özcan 1962, Artan 1988), İvesi (Özcan 1965) and Karakaş and Norduz (Tuncer and Cengiz 2009) sheep. The average S/P ratios were similar to the Lori (Abbasi et al 2008), Afshari, and Mehrabani (Ansari-Renani et al 2011) sheep, lower than those of the Zandi, Lori, and Balouchi (Ansari-Renani et al 2011) sheep, and higher than those of the Omani Native (Mahgoub et al 2010) and Bakhtiari (Mobini 2012) sheep.

The average secondary follicle densities and $\mathrm{S} / \mathrm{P}$ ratios of Karakaş and Norduz sheep were higher than those from Zom sheep (table 2), maybe because Zom sheep is exposed to worse environmental conditions or wool yield potential is lower than Karakaş and Norduz.

Table 3 shows a highly significant correlation between $\mathrm{S} / \mathrm{P}$ ratio and secondary follicle density in Karakaş and Norduz sheep $(P<0.01)$, but a negative correlation was found between $\mathrm{S} / \mathrm{P}$ ratio and primary follicle in Karakaş $(P<0.05)$ and Norduz $(P<0.01)$ sheep. In other words, the increase in the density of secondary follicles leads to an increase in the $\mathrm{S} / \mathrm{P}$ ratio, while the increase in the density of primary follicles causes a decrease in the $\mathrm{S} / \mathrm{P}$ ratio. A positive correlation was found between the secondary follicle and the S/P ratio and the primary follicle in Zom sheep $(P<0.05)$. Tuncer and Cengiz (2009) reported similar findings on Karakaş and Norduz sheep.

It can be concluded that the similar densities of primary follicles in the Karakaş, Norduz, and Zom sheep indicate a genetic similarity between the breeds. The fact that the densities of the secondary follicles and $\mathrm{S} / \mathrm{P}$ ratios were similar to the other local sheep breeds has shown that these three breeds can included in the sheep group that has coarse fleece.

\section{ACKNOWLEDGEMENTS}

This study was supported by Research Fund of the Van Yuzuncu Yil University. Project number FHD-2016-5286.

\section{REFERENCES}

Abbasi M, Gharzi A, Karimi H, Khosravinia H. 2008. Effects of sex on histological characteristics of various area of skin in an Iranian native breed of sheep. J Anim Vet Adv 7, 1503-1505.

Ansari-Renani HR, Moradi S, Baghershah HR, Ebadi Z, Salehi M, Seyed Momen SM, Ansari-Renani MY. 2011. Determination of wool follicle characteristics of Iranian sheep breeds, Asian-Aust J Anim Sci 24, 1173-1177.

Artan ME. 1988. Histology. İstanbul Üniv Vet Fak Yay, İstanbul, Turkey, Pp 259-282.

Bancroft JD, Cook HC. 1984. Manual of histological tecniques. Churchill Livingstone, London, UK.

Batu S, Özcan K. 1962. Researches on wool, follicle counts and fiber diameters in Akkaraman, Dağlıç, Kıvırcık and Merinos hybrids in Turkey. J Lalahan Lives Res Inst 10, 5-52.

Bingöl M, Gökdal Ö, Aşkın Y. 2007. Milk yield, live weights and body measurements of Norduz sheep grown in rural conditions. 5th National Animal Science Congress, 5-8 September, Van, Turkey.

Carter HB. 1955. The hair follicle group in sheep. Anim Breed Abstr 23, 101-116.

Chapman RE, Ward KE. 1979. Histological and biochemical features of the wool fibre and follicle. In: Black JL, Reis PJ (eds). Physiological and Environmental Limitations to Wool Growth. UNE Press, Armidale, Australia, Pp 193-208.

Corbett JL. 1979. Variation in wool growth with physiological state. In: Corbett JL (ed). Physiological and Environmental Limitations to Wool Growth. The University of New England Publishing Unit., Armidale Australia, Pp 79-98.

FAO. 1986. Sheep and goats in Turkey. FAO Animal Production and Health Paper 60. Food and Agriculture Organization of the United Nations, Rome, Italy.

Groves CP, Leslie Jr. DM. 2011. Rhinoceros sondaicus (Perissodactyla: Rhinocerotidae). Mamm Spec 43, 190-208.

Hatcher S. 2002. Fibre medullation, micron, marketing and management. NSW Agriculture, Orange Agricultural Institute, Orange NSW 2800, Australia.

Hatcher S, Johnson PR. 2004. Optimising genetic potential for wool production and quality through maternal nutrition. 2004 AFBM Network Conference. Orange NSW 2800, Australia.

Hiendleder S, Lewalski H, Wassmuth R, Janke A. 1998. The complete mitochondrial DNA sequence of the domestic sheep (Ovis aries) and comparison with the other major ovine haplotype. J Mol Evol 47, 441-448.

Hutchison G, Mellor DJ. 1983. Effects of maternal nutrition on the initiation of secondary wool follicles in foetal sheep. J Comp Pathol 93, 577-583.

Kaymakçı M. 2006. Advanced sheep breeding. İzmir İli Damızlık Koyun Yetiştiricileri Birliği Yayınları, 315, Bornova, İzmir, Turkey.

Kocamış H, Aslan Ş. 2004. Histological and histometrical study on the structure of Tuj breed sheep skin. Kafkas Univ Vet Fak Derg 10, 91-98.

Koncagül S, Akça N, Vural ME, Karataş A, Bingöl M. 2012. Morphological characteristics of Zom sheep. Kafkas Univ Vet Fak Derg 18, 829-837.

Krebs RE, Krebs CA. 2003. Groundbreaking scientific experiments, inventions and discoveries of the ancient world. Greenwood Press, Westport, USA.

Lyne AG. 1961. The postnatal development of wool follicles, sheeding and skin thickness in inbred Merino and Southdown-Merino crossbred sheep. Aust J Biol Sci 14, 141-156.

Mahgoub O, Kadim IT, Al-Dhahab A, Bello RB, Al-Amri IS, et al. 2010. An assessment of Omani Native sheep fiber production and quality characteristics. J Agric Mar Sci 15, 9-14. 
Mobini B. 2012. Morphometry of the hairs in different regions of skin in adult Bakhtiari sheep. Middle East J Sci Res 12, 603-607.

Özcan K. 1965. Studies on the skin folliciles of some sheep breeds in Turkey. Lalahan Zootechnical Research Institute Publications 17, Ankara, Turkey.

Özcan L. 1990. Sheep. Ministry of Food, Agriculture and Livestock, Ankara, Turkey.

Özfiliz N. 1992. Researches on skin and hair follicles in Karacabey Merinos sheep. $U \ddot{U}$ Vet Fak Derg 11, 1-15.

Özfiliz N, Balıkçıer M, Erdost H, Zık B. 2002. Histological and morphometric features of the skin of native and hybrid $\left(\mathrm{F}_{1}\right)$ sheep. Turk $J$ Vet Anim Sci 26, 429-438.

SAS, Statistical Analysis System. 2017. SAS/stat software hangen and enhanced. SAS Institute Inc., Cary, NC, USA.

Selçuk E. 1974. Researches on the relations between Merino, Morkaraman and Merino x Morkaraman follicle and some fleece properties grown at Ataturk University Farm. PhD Dissertation, Atatürk University of Agricultural Sciences, Erzurum, Turkey.

TUIK, Turkish Statistical Institute. 2016. Livestock Statistics. Turkish Statistical Institute, Istambul,Turkey.

Tuncer SS, Cengiz F. 2009. The relationships between fleeces follicle and fleece characteristics in Norduz and Karakas sheep. 6th National Animal Science Congress, Erzurum, Turkey.

Tuncer SS, Uslu S, Budağ C, Alarslan E, Karakuş K, et al. 2016. Effect of different levels of feed consumption on the quality of fleece and number of fiber follicles in Norduz lambs. Van Vet J 27, 37-42.

Winer BJ, Brown DR, Michels KM. 1991. Statistical Principles in Experimental Design. $3^{\text {rd }}$ ed. McGraw-Hill, New York, USA.

Zık B, Özfiliz N, Erdost H, Yağcı A. 1999. A histological and morphometrical study on the back region of Karayaka sheep skins. Kafkas Üniv Vet Fak Derg 5, 193-201. 